\title{
Evaluation of MIF -173 G/C Polymorphism in Turkish Patients with Ankylosing Spondylitis
}

\author{
Çevik Gürel ${ }^{1}$, Ahmet İnanır ${ }^{2}$, Ayşe Feyda Nursal ${ }^{3}$, Akın Tekcan $^{4}$, Aydın Rüstemoğlu ${ }^{1}$, Serbülent Yigit ${ }^{1}$ \\ ${ }^{1}$ Department of Medical Biology, Gaziosmanpaşa University School of Medicine, Tokat, Turkey \\ ${ }^{2}$ Department of Physical Medicine and Rehabilitation, Gaziosmanpaşa University School of Medicine, Tokat, Turkey \\ ${ }^{3}$ Department of Medical Genetics, Giresun University, School of Medicine, Giresun, Turkey \\ ${ }^{4}$ Ahi Evran University School of Health, Kırşehir, Turkey
}

Background: Ankylosing spondylitis (AS) is a chronic inflammatory disease mainly affecting the spine and sacroiliac joints. Macrophage migration inhibitory $(M I F)$ factor is a regulatory cytokine that inhibits random immune cell migration. MIF gene promoter polymorphisms play a role in the progression of several inflammatory disorders.

Aims: To investigate the relationship between the MIF gene - 173 G/C single-nucleotide polymorphism (SNP) and AS.

Study Design: Cross-sectional study.

Methods: In this study, a total of 161 AS and 194 normal controls were recruited. The MIF gene $-173 \mathrm{G} / \mathrm{C}$ SNP was analyzed by polymerase chain reaction using the restriction fragment length polymorphism method.
Results: There was no significant difference between groups in terms of genotype distribution ( $p>0.05$ ). When wild-type $\mathrm{G} / \mathrm{G}$ and $\mathrm{G} / \mathrm{C}+\mathrm{C} / \mathrm{C}$ genotypes are compared in terms of clinical characteristics, there is a significant difference between the average age and the duration of disease in AS patients $(\mathrm{p}<0.05)$.

Conclusion: No significant relationship between AS disease and $M I F-173 G / C$ polymorphism was found. $M I F-173 G / C$ polymorphism (C allele) may affect the time of onset and the duration of disease in AS patients.

Keywords: Ankylosing spondylitis, macrophage migration inhibitory factor, polymorphism
Ankylosing spondylitis (AS) is a chronic inflammatory disease that affects the spine and sacroiliac joints. AS is characterized by sacroiliac joint inflammation, peripheral inflammatory arthropathy and a totally lack or low levels of rheumatoid factor $(1,2)$. It influences EXTRA-ARTICULAR organs such as eye, skin and cardiovascular system organs less frequently. The prevalence of AS is about $0.1-1.4 \%$ (2). Most patients develop first symptoms in the second or third decade. Males are effected more frequently than females. AS is strongly associated with human leukocyte antigen B27 (HLA-B27) of the Major Histocompatibility Complex (MHC). First-degree relatives of patients with AS have approximately 10 times greater risk than the general population with HLA-B27-positive in terms of AS progression (3). The HLA-B27 occurring in 6 $\%$ of the US population but more than $90 \%$ of patients with AS. The prevalence of AS in different populations around the world generally correlates with the prevalence of HLA-B27 (4). Although the environment, genes, gender, age and race may be related to this disease, the etiology and pathogenesis of AS remain unknown.

Cytokines are polypeptides that constitute a class of chemical mediator molecule. Macrophage migration inhibitory factor $(M I F)$ is a multipotent molecule that regulates both in inbred and acquired immunity (5). It is known to be secreted $\mathrm{T}$ and B lymphocytes, neutrophils, dendritic cells, monocytes, basophiles and mast cells. MIF gene is localized on chromo- 
some 22q11.2 and composed of 3 exons (6). It stated that the altered levels of MIF may be play a role in several inflammatory diseases such as rheumatoid arthritis (RA). It is known that the reactive oxygen species (ROS) are effective at the beginning to in inflammatory diseases including AS. Besides, the pro-inflammatory cytokines are responsible for the increased of nitric oxide (NO). MIF take a critical role in the progression of some immune system diseases with the production of NO. But it uncertain the associations between the progression of AS and commonly known oxidative stress markers (7). Therefore, we think that it should be investigate whether -173 G>C MIF gene polymorphism influence AS pathogenesis. It has been shown that MIF take a considerable role in the progression of inflammatory diseases (6). Two polymorphisms have been identified in the $M I F$ gene promoter: these a silent polymorphism, $-173 G>C$ (rs755622), and a nucleotide repeat polymorphism $C A T T_{5-8}$. These polymorphisms are related to the risk and intensity of the inflammatory disease (5). Based on these findings, in this study, we investigated the MIF promoter $-173 \mathrm{G} / \mathrm{C}$ polymorphism in Turkish AS patients. Our study is the first study that analyzes MIF promoter polymorphism in AS.

\section{MATERIALS AND METHODS}

Subjects
Macrophage migration inhibitory gene promoter variation
was analyzed in 161 AS patients and 194 healthy controls.
Subjects included to the study were greater than 18 years. Pa-
tients were diagnosed in Physical Medicine and Rehabilita-
tion clinics at our hospital. All patients fulfilled the New York
criteria for AS and also, all participants had taken part in our
previous study (3). The majority of AS patients has sacro-iliac
involvement. The patients without sacro-iliac symptoms were
diagnosed with HLA-B27 positivity and two other symptoms
such as hip and other joint involvements. Clinical examina-
tions were performed for all patients. The control group were
chosen according to diagnosis criteria of AS. Data collection
were performed according to some informations such as age,
disease duration, smoking status, exercise habit, peripheral/
extraarticular involvement and several clinical characteristics.
Written consent was obtained from all patients and controls be-
fore the study, according to the ethical guidelines of the 2008
Declaration of Helsinki and the study was accepted by ethi-
cal committee of School of Medicine (13-KAEK-178). Both
the groups were of white Caucasian origin, from the Blacksea
region of Turkey. Bath Ankylosing spondylitis disease activ-
ity index (BASDAI) are the most widely used tools for the

assessment of AS functional status and activity. The activity status of patients was evaluated by BASDAI (8). Clinical and laboratory findings were compared between the groups.

\section{Genotype determination}

DNA was extracted from $2 \mathrm{~mL}$ of venous blood according to Genomic DNA isolation kit procedure (Sigma-Aldrich; Taufkirchen, Germany) and stored at $-20^{\circ} \mathrm{C}$. The $M I F$ gene genotyped with the PCR based-Restriction Fragment Length Polymorphism (RFLP) technique. The PCR primers were: sense, 5'-ACT-AAG-AAA-GAC CCG-AGG-C-3'; antisense, 5'-GGG-GCA-CGT-TGG-TGT-TTA-C-3'. These were brought to a final volume of $25 \mu \mathrm{L}$ (9).

DNA was amplified for 30 cycles with denaturation at $95^{\circ} \mathrm{C}$, annealing at $60^{\circ} \mathrm{C}$ and extension at $72^{\circ} \mathrm{C}$ for 30 cycles $(5 \mathrm{~min}$, $45 \mathrm{~min}, 45 \mathrm{~min}, 45 \mathrm{sec}$ ) and $72^{\circ} \mathrm{C}$ as for 7 minutes to finish the reaction. Final PCR products were digested in a $30 \mu \mathrm{L}$ final volume using reaction buffer $(2 \mu \mathrm{l})$ and Alu enzyme (1 $\mu \mathrm{L})$ at $37^{\circ} \mathrm{C} 12$ hour. The digested fragments were loaded to $2 \%$ agarose gel stained with ethidium bromide and visualized using UV transillumination (Quantum-ST4, Vilber Lourmat; Collégien, France).

\section{Statistical analysis}

Statistical analyses were performed using SPSS Statistical Package for Social Sciences Version 20.0 (IBM Corp.; Armonk, NY, USA) and the OpenEpi Info software package version 3.01 (10). The data were given as mean \pm SD (standard deviation) and (min-max). The allele frequencies and genotype distributions analyzed with chi square $\left(\mathrm{x}^{2}\right)$ test in patients and control groups. Odds ratio (OR) (OR) and 95\% confidence interval $(\mathrm{CI})$ were used for the assessment of risk factors. $\mathrm{P}$ values less than 0.05 were considered as significant.

\section{RESULTS}

Allele and genotype frequencies of SNPs were calculated and tested for departure from Hardy-Weinberg equilibrium using the Chi-square test. The demographic characteristics of the patients with AS and controls are shown in Table 1. There was no difference between patients and controls in terms of mean age $(\mathrm{p}>0.05)$. The mean age \pm standard deviation (SD) was $39.92 \pm 8.78$ and $39.37 \pm 10.37$ in in patients and control group, respectively. While gender rate was 84 female $(52.2 \%)$ and 77 male $(47.8 \%)$ in patient group, in the control group, it was $111(56.42 \%)$ and $83(42.8 \%)$, respectively. Females constituted the majority of cases in both patient and control groups $(52.1 \%$ and $57.2 \%)$ respectively. 
TABLE 1. Baseline demographic characteristics of patients with AS and healthy controls

\begin{tabular}{|c|c|c|c|}
\hline Individual characteristic & $\begin{array}{c}\text { Patients } \\
(n=161)(\%)\end{array}$ & $\begin{array}{c}\text { Control } \\
(\mathrm{n}=194)(\%)\end{array}$ & $\mathrm{p}$ \\
\hline Average age & $37.92 \pm 8.78$ & $39.37 \pm 10.37$ & 0.162 \\
\hline \multicolumn{4}{|l|}{ Gender } \\
\hline Women & $84(52.2 \%)$ & $111(57.2 \%)$ & \\
\hline Man & $77(47.8 \%)$ & $83(42.8 \%)$ & \\
\hline
\end{tabular}

TABLE 2. Distribution of MIF gene -173 polymorphism and allele frequencies between AS patients and controls

\begin{tabular}{lccc}
\hline Genotype & Patients & Control & $p$ \\
\hline GG & $116(72.0 \%)$ & $136(70.1 \%)$ & \\
GC & $42(26.1 \%)$ & $49(25.3 \%)$ & 0.356 \\
CC & $3(1.9 \%)$ & $9(4.6 \%)$ & \\
Allel & & & \\
G & $274(85.0 \%)$ & $321(82.7 \%)$ & 0.455 \\
C & $48(15.0 \%)$ & $67(17.3 \%)$ & \\
\hline
\end{tabular}

TABLE 3. Comparison of some clinical paremeters between patients with

\begin{tabular}{lccc}
\multicolumn{4}{c}{ GG allele and GC+CC alleles } \\
\hline & GG $(\mathrm{n}=116)$ & $\mathrm{GC}+\mathrm{CC}(\mathrm{n}=45)$ & $\mathrm{p}$ \\
\hline Average age (years) & $38.83 \pm 8.87$ & $35.57 \pm 8.18$ & 0.034 \\
Diagnosis age mean (years) & $32.62 \pm 8.77$ & $30.73 \pm 7.73$ & 0.208 \\
Disease duration mean (years) & $6.56 \pm 5.39$ & $4.80 \pm 3.57$ & 0.045 \\
ESR (mm/hour) & $16.82 \pm 13.64$ & $15.02 \pm 13.60$ & 0.443 \\
Schober Test (cm) & $4.07 \pm 1.58$ & $4.36 \pm 1.34$ & 0.290 \\
BASDAI & $2.80 \pm 1.34$ & $2.53 \pm 0.91$ & 0.212
\end{tabular}

ESR: erythrocyte sedimentation rate; BASDAI: BATH ankylosing spondylitis disease activity index
The distributions of $M I F-173 C / G$ allele frequencies in patients with AS and controls are given in Table 2. We found no statistically significant difference in the genotype frequencies of the MIF gene polymorphism in patients and control groups ( $p>0.05$ ). The $M I F$ gene $\mathrm{G}$ allele was $85 \%$ in patients and $82.7 \%$ in the control group, while the $\mathrm{C}$ allele frequency was $15 \%$ in patients and $17.3 \%$ in the control group. In the combined analysis of the MIF gene, the GG/GC/CC combined genotype was no found to increase the risk of AS compared to the controls. It was found a significant difference between AS patients with homozygous $\mathrm{G} / \mathrm{G}$ genotype and AS patients with heterozygous $\mathrm{G} / \mathrm{C}$ and homozygous $\mathrm{C} / \mathrm{C}$ genotype in terms of the average age and disease duration $(\mathrm{p}<0.05)$. Additionally, there was not any difference on patients in terms of diagnosis age, the results of erythrocyte sedimentation rate (ESR) measurements, Schober test measurements, the results of BASDAI ( $>0.05$ ) (Table 3). We found no association between $M I F$ gene polymorphism and sacroiliac involvement, HLA-B27 positivity, new bone arrangement, ocular involvement, hip involvement, cervical involvement, oral aphthous or familial history ( $p>0.05)$ (Table 4).

\section{DISCUSSION}

Ankylosing spondylitis is associated with chronic inflammation of the sacroiliac and peripheral joints. Although the pathogenesis of AS is not known, genetic factors play a considerable role in its pathogenesis (11). MIF is an important cytokine as proinflammatory mediator related in the regulation of immunity. Besides, $M I F$ is a key regulator in a variety of biological

TABLE 4. Comparison of disease charecteristics between patients with $\mathrm{GG}$ allele and $\mathrm{GC}+\mathrm{CC}$ alleles

\begin{tabular}{|c|c|c|c|c|c|}
\hline Characteristics & Status & Total n (\%) & GG n (\%) & $\mathrm{GC}+\mathrm{CC}$ n $(\%)$ & $\mathrm{p}$ \\
\hline \multirow{2}{*}{ Sacro-iliac involvement } & Yes & $130(80.7)$ & $94(72.3)$ & $36(27.7)$ & \multirow{2}{*}{$>0.05$} \\
\hline & No & $31(19.3)$ & $22(71.0)$ & $9(29.0)$ & \\
\hline \multirow{2}{*}{ HLA-B27 positivity } & Yes & $109(67.7)$ & $38(73.1)$ & $14(26.9)$ & \multirow{2}{*}{$>0.05$} \\
\hline & No & $52(32.3)$ & $78(71.6)$ & $31(28.4)$ & \\
\hline \multirow{2}{*}{ New bone arrangement } & Yes & $40(24.9)$ & $29(72.5)$ & $11(27.5)$ & \multirow{2}{*}{$>0.05$} \\
\hline & No & $121(75.1)$ & 87 (71.9) & $34(28.1)$ & \\
\hline \multirow{2}{*}{ Ocular involvement } & Yes & $24(15)$ & $15(62.5)$ & $9(37.5)$ & \multirow{2}{*}{0.324} \\
\hline & No & $137(85)$ & $101(73.7)$ & $36(26.3)$ & \\
\hline \multirow{2}{*}{ Hip involvement } & Yes & $51(31.7)$ & $38(74.5)$ & $13(25.5)$ & \multirow{2}{*}{0.708} \\
\hline & No & $110(68.3)$ & $78(70.9)$ & $32(29.1)$ & \\
\hline \multirow{2}{*}{ Cervical involvement } & Yes & $19(11.8)$ & $13(68.4)$ & $6(31.6)$ & \multirow{2}{*}{0.786} \\
\hline & No & $142(88.2)$ & $103(72.5)$ & $39(27.5)$ & \\
\hline \multirow{2}{*}{ Oral aphthous } & Yes & $38(23.6)$ & $27(71.1)$ & $11(28.9)$ & \multirow{2}{*}{$>0.05$} \\
\hline & No & $123(76.4)$ & $89(72.4)$ & $34(27.6)$ & \\
\hline \multirow{2}{*}{ Familial history } & Yes & $37(23)$ & $130(80.7)$ & $29(78.4)$ & \multirow{2}{*}{0.406} \\
\hline & No & $124(77)$ & $31(19.3)$ & $87(70.2)$ & \\
\hline
\end{tabular}


functions including proinflammatory actions, immunological reactions and carcinogenesis. $M I F$ expression anomalies are effective in the progression of chronic inflammatory diseases. We analyzed whether $\mathrm{G} / \mathrm{C}$ polymorphism at the $M I F$ gene promoter predisposes to AS disease in this paper. Also, this study is the first report to evaluate the $M I F$ gene polymorphism among AS patients. Because of its relationship with inflammation, the $M I F$ gene and its polymorphisms have been investigated in association with inflammatory rheumatic diseases. The $M I F-173 \mathrm{C}$ allele is obviously related to the disease as a result of their study that has been conducted with juvenile idiopathic arthritis (JIA) patients (11). The $M I F-173 C$ allele affect a potential activator protein 4 (AP-4) that may affect $M I F$ expression $(12,13)$.

MIF levels are clearly high in patients with the $M I F-173 \mathrm{C}$ allele, so researchers compared levels of the $\mathrm{G} / \mathrm{C}$ and $\mathrm{C}$ alleles in the serum and synovial fluid of JIA patients (14). This research has supported that this can be predictive for the glucocorticoid treatment duration. Liu et al. (15) have examined the relationship between Chinese rheumatoid arthritis (RA) and $M I F-173$ polymorphism. They have not found a significant association between $\mathrm{G} / \mathrm{G}, \mathrm{G} / \mathrm{C}$ and $\mathrm{C} / \mathrm{C}$ genotype distributions whereas they have shown that the risk of RA disease is high in individuals who carry $\mathrm{C} / \mathrm{C}$ genotype. In another study related to RA patients, it has been stated that $\mathrm{C}$ allele is related to the activity of RA disease (16). It was have determined that the $M I F-173 \mathrm{C}$ is related to inflammatory sensitivity of polyarthritis whereas it is not in association with the intensity of the disease (17). In another study, they have shown that particularly $M I F-173 \mathrm{C}$ allele leads to increased risk of early onset of RA disease (18). MIF gene polymorphism is studied in many different inflammatory diseases. The association between the $M I F-173 C / C$ genotype and predisposition to ulcerative colitis was also found on the Chinese people (19). The C/C genotype is frequently seen in patients with pancolitis, although no genotype difference has been found to be associated with ulcerative colitis (20). Przybylowska et al. (21) have shown that there is no difference between patients with respect to their genotypes in inflammatory bowel disease but MIF -173 $\mathrm{G} / \mathrm{C}$ polymorphism $\mathrm{C}$ allele leads to increase in the risk of ulcerative colitis disease. HLA-B27 is an important indicator on AS progression (3). The rate of HLA-B27 varies in different studies in Turkey. Gunal et al. (22) and Cinar et al. (23) reported that the proportion of HLA-B27 positivity was $70.0 \%$ and $66.7 \%$. Although HLA-B27 rate was lower than expected and determined as $32.3 \%$ on patients. Various genetic and environmental factors may contribute to the decreased HLA-B27 frequency observed among Turkish AS patients. Sample size also plays a role (22).

It was determined that MIF polymorphisms may vary predictably for certain diseases, especially those related to the immune system. $M I F-173 \mathrm{C}$ allele and $\mathrm{C} / \mathrm{C}$ genotype is high in asthmatic children (24). Also, it was reported that MIF-173 $\mathrm{C}$ gene polymorphisms are positively associated to psoriasis (25). MIF gene $-173 \mathrm{C}$ allele frequency is high in secondary sarcoidosis erythema nodosum patients (26). Additionally, C allele and $\mathrm{C} / \mathrm{C}$ genotype are highly seen in systemic lupus patients (27). It was expressed that plasma MIF levels increase in Still's disease patients with C/C genotype (28). Previous studies in children with Henoch-Schönlein purpura disease (29) and cutaneous vasculitis patients have shown that there is no genotype-phenotype association or $\mathrm{C}$ allele difference in these patients (30).

In this study, we analyzed the relationship between AS disease, which is an inflammatory disease, and MIF polymorphism, which has a role in many inflammatory diseases. We have not determined the allele and genotype differences between AS patients and control group. We found a statistically significant difference in the average age of patients who carry the $\mathrm{C}$ allele and in the duration of disease. These findings show that the $\mathrm{C}$ allele can lead to early onset disease.

In conclusion, no previous study has examined the relationship between the AS disease and the $M I F$ gene -173 G/C polymorphism in both Turkish. We have not found a relationship between AS disease and $M I F-173 G / C$ polymorphism, but these results could change with further study if more patients and control samples are compared to each other with respect to age and gender. We have shown that the $M I F-173 \mathrm{G} / \mathrm{C}$ polymorphism ( $\mathrm{C}$ allele) can affect the time of onset and the duration of disease in AS patients.

Ethics Committee Approval: Ethics committee approval was received for this study from the ethics committee of Gaziosmanpaşa University School of Medicine (Approval no: 13-KAEK-178).

Informed Consent: Written informed consent was obtained from the patients who participated in this study.

Peer-review: Externally peer-reviewed.

Author contributions: Concept - A.İ., S.Y., Ç.G.; Design - Ç.G., A.T., S.Y.; Supervision - S.Y.; Resource - A.İ., Ç.G., S.Y.; Materials - Ç.G., A.T., A.F.N., S.Y., A.R.; Data Collection and/or Processing - Ç.G., S.Y., A.T., A.R.; Analysis and/or Interpretation - Ç.G., S.Y., A.T., A.F.N., A.R.; Literature Search - Ç.G., A.T., A.F.N., S.Y.; Writing - Ç.G., A.T., A.F.N.; Critical Reviews - A.T., A.F.N., S.Y.

Conflict of Interest: No conflict of interes was declared by the authors.

Financial Disclosure: The authors declared that this study has received no financial support. 


\section{REFERENCES}

1. Daikh DI, Chen PP. Advances in managing ankylosing spondylitis. F1000Prime Rep 2014;6:78. [CrossRef]

2. Tsui FW, Tsui HW, Akram A, Haroon N, Inman RD. The genetic basis of ankylosing spondylitis: new insights into disease pathogenesis. Appl Clin Genet 2014;7:105-15. [CrossRef]

3. Yigit S, Inanir A, Tural S, Filiz B, Tekcan A. The effect of IL-4 and MTHFR gene variants in ankylosing spondylitis. $Z$ Rheumatol 2015;1:60-6. [CrossRef]

4. Smith JA. Update on ankylosing spondylitis: current concepts in pathogenesis. Curr Allergy Asthma Rep 2015;15:489. [CrossRef]

5. Falvey JD, Bentley RW, Merriman TR, Hampton MB, Barclay ML, Gearry RB, et al. Macrophage migration inhibitory factor gene polymorphisms in inflammatory bowel disease: an association study in New Zealand Caucasians and meta-analysis. World J Gastroenterol 2013;19:6656-64. [CrossRef]

6. Renner P, Roger T, Calandra T. Macrophage migration inhibitory factor: gene polymorphisms and susceptibility to inflammatory diseases. Clin Infect Dis 2005;41:513-9. [CrossRef]

7. Kozaci LD, Sari I, Alacacioglu A, Akar S, Akkoc N. Evaluation of inflammation and oxidative stress in ankylosing spondylitis: a role for macrophage migration inhibitory factor. Mod Rheumatol 2010;20:34-9. [CrossRef]

8. Park SH, Choe JY, Kim SK, Lee H, Castrejón I, Pincus T. Routine assessment of Patient Index Data (RAPID3) and Bath Ankylosing Spondylitis Disease Activity Index (BASDAI) scores yield similar information in 85 Korean patients with Ankylosing Spondylitis seen in usual clinical care. J Clin Rheumatol 2015;21:300-4. [CrossRef]

9. Makhija R, Kingsnorth A, Demaine A. Gene polymorphisms of the macrophage migration inhibitory factor and acute pancreatitis. JOP 2007;8:289-95.

10. Dean AG, Sullivan KM, Soe MM. OpenEpi: Open Source Epidemiologic Statistics for Public Health, Version. Availabe from: www.OpenEpi.com (accessed 2015/09/17).

11. Donn RP, Shelley E, Ollier WE, Thomson W, British Pediatric Rheumatology Study Group. A novel 5'-flanking region polymorphism of macrophage migration inhibitory factor is associated with systemic-onset juvenile idiopathic arthritis. Arthritis Rheum 2001;44:1782-5. [CrossRef]

12. Donn R, Alourfi Z, De Benedetti F, Meazza C, Zeggini E, Lunt $\mathrm{M}$, et al. Mutation screening of the macrophage migration inhibitory factor gene: positive association of a functional polymorphism of macrophage migration inhibitory factor with juvenile idiopathic arthritis. Arthritis Rheum 2002;46:2402-9. [CrossRef]

13. Radstake TR, Sweep FC, Welsing P, Franke B, Vermeulen SH, Geurts-Moespot A, et al. Correlation of rheumatoid arthritis severity with the genetic functional variants and circulating levels of macrophage migration inhibitory factor. Arthritis Rheum 2005;52:3020-9. [CrossRef]

14. De Benedetti F, Meazza C, Vivarelli M, Rossi F, Pistorio A, Lamb R, et al. Functional and prognostic relevance of the -173 polymorphism of the macrophage migration inhibitory factor gene in systemic-onset juvenile idiopathic arthritis. Arthritis Rheum 2003;48:1398-407. [CrossRef]

15. Liu R, Xu N, Wang X, Shen L, Zhao G, Zhang $H$, et al. Influence of MIF, CD40, and CD226 polymorphisms on risk of rheumatoid arthritis. Mol Biol Rep 2012;39:6915-22. [CrossRef]

16. Llamas-Covarrubias MA, Valle $Y$, Bucala R, Navarro-Hernández RE, Palafox-Sánchez CA, Padilla-Gutiérrez JR, et al. Macrophage migration inhibitory factor (MIF): genetic evidence for participation in early onset and early stage rheumatoid arthritis. Cytokine 2013;61:759-65. [CrossRef]

17. Barton A, Lamb R, Symmons D, Silman A, Thomson W, Worthington J, et al. Macrophage migration inhibitory factor (MIF) gene polymorphism is associated with susceptibility to but not severity of inflammatory polyarthritis. Genes Immun 2003;4:487-91. [CrossRef]

18. Martínez A, Orozco G, Varadé J, Sánchez López M, Pascual D, Balsa A, et al. Macrophage migration inhibitory factor gene: influence on rheumatoid arthritis susceptibility. Hum Immunol 2007;68:744-7. [CrossRef]

19. Fei BY, Lv HX, Yang JM, Ye ZY. Association of MIF-173 gene polymorphism with inflammatory bowel disease in Chinese Han population. Cytokine 2008;41:44-7. [CrossRef]

20. Nohara H, Okayama N, Inoue N, Koike Y, Fujimura K, Suehiro $\mathrm{Y}$, et al. Association of the $-173 \mathrm{G} / \mathrm{C}$ polymorphism of the macrophage migration inhibitory factor gene with ulcerative colitis. J Gastroenterol 2004;39:242-6. [CrossRef]

21. Przybyłowska K, Mrowicki J, Sygut A, Narbutt P, Dziki Ł, Dziki A, et al. Contribution of the $-173 \mathrm{G} / \mathrm{C}$ polymorphism of macrophage migration inhibitory factor gene to the risk of inflammatory bowel diseases. Pol Przegl Chir 2011;83:76-80. [CrossRef]

22. Gunal EK, Sarvan FO, Kamali S, Gul A, Inanc M, Carin M, et al. Low frequency of HLA-B27 in ankylosing spondylitis patients from Turkey. Joint Bone Spine 2008;75:299-302. [CrossRef]

23. Cinar M, Akar H, Yilmaz S, Simsek I, Karkucak M, Sagkan RI, et al. A polymorphism in ERAP1 is associated with susceptibility to ankylosing spondylitis in a Turkish population. Rheumatol Int 2013;33:2851-8. [CrossRef]

24. Wu J, Fu S, Ren X, Jin Y, Huang X, Zhang X, et al. Association of MIF promoter polymorphisms with childhood asthma in a northeastern Chinese population. Tissue Antigens 2009;73:3026. [CrossRef]

25. Donn RP, Plant D, Jury F, Richards HL, Worthington J, Ray DW, et al. Macrophage migration inhibitory factor gene polymorphism is associated with psoriasis. J Invest Dermatol 2004;123:484-7. [CrossRef]

26. Amoli MM, Donn RP, Thomson W, Hajeer AH, Garcia-Porrua C, Lueiro M, et al. Macrophage migration inhibitory factor gene polymorphism is associated with sarcoidosis in biopsy proven erythema nodosum. J Rheumatol 2002;29:1671-3.

27. Sánchez E, Gómez LM, Lopez-Nevot MA, González-Gay MA, Sabio JM, Ortego-Centeno N, et al. Evidence of association of macrophage migration inhibitory factor gene polymorphisms with systemic lupus erythematosus. Genes Immun 2006;7:433-6. [CrossRef] 
28. Wang FF, Huang XF, Shen N, Leng L, Bucala R, Chen SL, et al. A genetic role for macrophage migration inhibitory factor (MIF) in adult-onset Still's disease. Arthritis Res Ther 2013;15:65. [CrossRef]

29. Nalbantoglu S, Tabel Y, Mir S, Berdeli A. Lack of association between macrophage migration inhibitory factor gene promoter (-173 G/C) polymorphism and childhood Henoch-
Schönlein purpura in Turkish patients. Cytokine 2013;62:1604. [CrossRef]

30. Amoli MM, Martin J, Miranda-Filloy JA, Garcia-Porrua C, Ollier WE, Gonzalez-Gay MA. Lack of association between macrophage migration inhibitory factor gene (-173 G/C) polymorphism and cutaneous vasculitis. Clin Exp Rheumatol 2006;24:576-9. 